\title{
The call for relevance: South African psychology ten years into democracy.
}

\author{
Cheryl de la Rey \\ Deputy Vice-Chancellor (Research and Innovation), University of Cape Town, \\ South Africa
}

\section{Jonathan Ipser*}

Department of Psychology, University of Cape Town, Private Bag,

Rondebosch, 7701, South Africa

e-mail: jipser@humanities.uct.ac.za

A number of scholars during the 1980s and early 1990s questioned the relevance of psychology in South Africa. In this paper we characterise the nature of what became known as the 'relevance debate', and then investigate whether South African psychology has become more relevant during the nation's first ten years of democracy. Themes which are identified with respect to this issue include the apparent increasing representation of marginalised groups within South African psychology, the conscious responsiveness of psychologists to post-apartheid policy imperatives and issues, their alignment with international theoretical trends, and finally, an increasing recognition of the political nature of South African psychology. The authors conclude that a more productive approach within future debates regarding relevance in psychology would be to examine the nature of knowledge production within the discipline.

* To whom correspondence should be addressed

From the latter half of the 1980s into the early 1990s many South African psychologists earnestly debated the question of how psychology could become more relevant to the local socio-political context. Such was the fervour of the debates among some groups of psychologists that it was labelled 'a state of crisis' (Shefer, 1988, p. 31). This reference to a crisis was not uniquely South African. A crisis was identified within the international arena as well, concerning the degree to which the Eurocentric 'Western' tradition of positivistic empiricism in psychology could be regarded as relevant to the everyday lives of people living in vastly different social contexts. 
This 'crisis' took on a distinctive flavour in South Africa, however. Due to the socio-economic inequities promulgated by the policies of the apartheid regime, psychology was almost the exclusive reserve of what were perceived as an elitist group of middle-class white men. There was a crisis in confidence regarding the applicability of psychological knowledge and practice to the social problems in South Africa, leading to a search for 'relevance' in psychology.

Against the backdrop of apartheid, several psychologists argued that the proper objective of South African psychology was to redress the consequences of human rights abuses visited upon the majority black population by apartheid policies. However, there were various proposals on how this was to be achieved.

In an attempt towards the end of the apartheid era to address this so-called 'crisis', some psychologists focused on trying to expose racism, sexism and class oppression, as well as their consequences, in their teaching, research and academic publications. At the time there was very little being taught formally about any of these issues at universities. Offering a critical voice in opposition to the mainstream became one form of response in the search for relevance. The call for liberatory psychology and a psychology for empowerment emerged with some psychologists such as Andy Dawes (1985) arguing that psychologists should double as activists. The integration of theoretical criticism and political activism became a motif for those such as Mohamed Seedat (e.g. Seedat, 1998) who began to work within a paradigm that stressed the importance of activity in the interests of community empowerment.

\section{THE TURN TO COMMUNITY}

The emergence of new content areas was a visible response to the call for relevance in psychology. Indeed, one of the key shifts was in a turn to community. At the time the impact was such that Seedat, Cloete and Shochet (1988, p. 39) noted that 'many psychologists have boarded the community psychology wagon'. The turn to the discourse of the community in response to the crisis of relevance was not done uncritically, however. Several psychologists published papers raising problems with the simplistic manner in which some psychologists adopted community psychology models (e.g. Isemonger, 1990). In 2004 most departments of psychology teach community psychology and almost all professional training programmes in clinical and counselling psychology have a community component.

From 1994 onwards the call for relevance manifested in the form of two strands of response: firstly, an attempt to change the demographic profile of psychologists and secondly, a conscious responsiveness to post-apartheid policy imperatives and issues. 


\section{CHANGES IN REPRESENTATION}

Changing the demographic profile of psychology as a profession and an area of scholarship has also been used as a criterion to assess the relevance of South African psychology.

In an attempt to shift the racial and gender bias evident in psychological research, a number of projects aimed at the development of authorship among black psychologists were initiated. Shortly after the launch of the Psychological Society of South Africa in 1994, the first non-racial professional organisation for psychology, a special issue on black authorship was published in its flagship publication, the South African Journal of Psychology. What was special about this issue was not only that it featured articles authored by black psychologists but also that the editor at the time handed the entire editorial process over to a black editorial group. Self-empowerment groups of women and black psychologists have successfully managed several similar projects. These have not been limited to psychologists only. The most recent of these projects led by psychologists included writers from disciplines such as sociology, history, gender studies and anthropology (see Duncan, Gqola, Hofmeyer, Shefer, Malunga \& Mashige, 2002). The critical success factors in these initiatives have been identified as a sense of collectivity and ownership of the process, a firm intent to conduct peer reviews in a constructive spirit, commitment on the part of the participants and a strong degree of overlap between personal and project goals (van Niekerk, Diedricks, de la Rey, Shefer \& Duncan, 1998).

In an article published in this issue of the SAJP, Duncan, van Niekerk, and Townsend report that only $18 \%$ of the psychologists registered with the Health Professions Council of South Africa for whom group membership is known are black. Although this number is low, Duncan et al. conclude from an analysis of authorship trends in the South African Journal of Psychology between 1994 and 2003, that blacks are well represented in terms of publications, with $22 \%$ of the papers being published by black authors. This represents an increase of almost three-fold from the estimate of the number of articles authored by blacks in 1994. However, the swell of black publishing output can largely be attributed to an increase in the number of male, as opposed to female authors.

In another article published in this issue of the SAJP, and which reviews the degree to which women were represented as authors for articles published in the SAJP between 1994 and the end of 2003, Shefer, Shabalala and Townsend conclude that there was a slightly positive trend towards increasing numbers of contributing women over the decade. ${ }^{1}$ Women represented just under half of the authors during that time period (44\%). This compares favourably to the figure of $31.5 \%$ obtained by Seedat, in his survey of articles published in seven South African psychological journals between 1948 and 1988 (Seedat, 1998).

The changes in demographics have been mirrored by a shift towards relevance in the focus and content of psychology as well. 


\section{CHANGES IN CONTENT}

The publication of the Reconstruction and Development Programme (RDP) post 1994 as the blueprint for the reconstruction of a South African society led to a plethora of workshops within every sector of our society examining how its projects and activities would fit in with this plan. The Programme targeted every sphere of society - economic, social, legal, political, moral, cultural and environmental. So zealous were efforts to respond that phrases such as the 'RDP bandwagon' came into common usage within psychology. At the subsequent annual national psychology congress the programme included a workshop on psychology and the RDP. Furthermore, the keynote address was delivered by the Deputy Minister for Welfare and Population Development, Geraldine Fraser-Moleketi, who focused on how psychologists need to redirect their skills to fulfil the objectives of the RDP. Hence, psychology, like the other sectors, became keenly concerned about mapping out its role in relation to the RDP.

Nevertheless, the RDP as a framework document for government policy and implementation gave way to a more complex macro-economic strategy, and with it attention to RDP-type projects. In aligning themselves with the government's focus on redevelopment during the first five years after the first democratic elections, many psychologists who had previously been at the forefront of anti-apartheid critique turned towards policy development, and specifically mental health policy. The provision and the accessibility of mental health services became a key area of attention (see Foster, Pillay \& Freeman, 1997). The discourse of mental health amongst psychologists dovetailed with the RDP in that there was a special section of the RDP devoted to mental health.

Another trend in response to societal events post 1994 was the surfacing of articles on the Truth and Reconciliation Commission (TRC). The TRC became a new key focus for South African psychology. There was the direct involvement of psychologists in the TRC process itself in the form of provision of counselling services. In addition, a few individual psychologists took up official appointments as commissioners. Direct involvement in the TRC also included the assistance a few psychologists provided with applications for amnesty by perpetrators. This type of involvement came under serious criticism from black psychologists who viewed this as a continuation of the complicity by psychologists under apartheid (Magwaza, 2001; Nicholas, 2000).

Besides direct involvement in the TRC, psychologists also researched the TRC, the process by which it carried out its duties, and its impact. Questions such as the efficacy of the psychological support services (Hamber, 1998), healing and the TRC (de la Rey \& Owens, 1998), and the impact of public testimony (Kaminer, Stein, Mbanga \& Zungu-Dirwayi, 2001) constituted the focus of several studies. Unsurprising, perhaps, research on the TRC has waned following the conclusion of the TRC process and the release of the final report.

A sentiment held by many was that psychology would only be relevant in South Africa once it moved away from its white elitist image and embraced knowledge held 
by laypeople and traditional healers (Louw, 1992). It was regarded as incumbent upon psychologists to take steps to reduce the mystification associated with its knowledge domain, particularly with respect to its involvement in community projects (Berger \& Lazarus, 1987). Opening the channels of communication between psychological practitioners and traditional healers was also viewed as a means to realise the possibility of recruiting the aid of the more numerous traditional healers in mental health services.

Another type of response to what was regarded as the Eurocentric nature of psychology in South Africa (Naidoo, 1996) took the form of arguing that Africans required their own unique psychology. Holdstock (1981) was one of the earliest scholars to argue for the necessity of a psychology which is sensitive to the African cultural milieu, by suggesting that South African psychology should incorporate traditional healers. Other scholars have gone even further in arguing for the development of a psychology which is utterly distinct from Eurocentric models of psychology, in recognition that 'Africans have a cosmology, ontology, eschatology, epistemology and axiology that is quintessentially their own' (Bodibe, 1993, p. 54).

\section{HAS SOUTH AFRICAN PSYCHOLOGY BECOME MORE RELEVANT SINCE 1994?}

To answer this question one of the authors conducted an electronic search for the term 'relevance' within all the articles published in the SAJP between 1994 and 2004 (Volume 34, Number 1), inclusive. Due to the very low return rate yielded by this strategy, it was followed by a manual search. This was only partially more successful, as few articles refer to the relevance debate as such. The same finding occurred with regards to the Psychology in Society journal, in which the 'relevant' articles were identified by means of scanning the titles of the articles between 1994 and 2003, inclusive. The abstracts of those articles that seemed promising were read to determine whether the articles were worthwhile retrieving

The paucity of articles in which the relevance debate is discussed over the last decade could be ascribed to it having become less of an issue. One reason for this might be the particular form this debate took in South Africa, where it was often phrased in terms of opposition to inequities introduced by the apartheid regime (Dawes, 1985; Hayes, 2003). Of course, the subsequent removal of this regime does not excuse the failure to interrogate the relevance of psychology, as not only has it left an enduring legacy of socio-economic inequalities, but also necessitates psychological support in adjustment to the rapid social changes introduced through social improvement schemes.

Since 1994 the concept of relevance has by and large been interpreted as a form of social responsiveness, judged in terms of the degree to which psychology has responded to government-led initiatives to promote social and economic development. The disappearance of the relevance debate may also reflect the perception that 
psychology is indeed addressing the socio-political concerns in South Africa which progressive psychologists maintain is its primary purpose.

Macleod (2004) recently reviewed all articles over the last five years to be published in the SAJP, as well as articles from the same period retrieved through PsycINFO using the key words 'South Africa', as part of the National Research Foundation's 'Shifting the boundaries of knowledge - the role of social sciences, law and humanities' project. She compared the content trends with the priority areas in the Eastern Cape's Growth and Development Plan. Her conclusion was that psychology has a long way to go before it can establish its relevance credentials. Moreover, her review of the SAJP articles reveals that only 3 articles out of 147 dealt with what must be one of the most pressing socio-political issues of the day in Africa, HIV/AIDS. ${ }^{2}$

Although changes in both content and representation are important, perhaps a deeper level of examining change is at the level of theory and methodology. At a theoretical level, South African psychology has aligned itself with trends seen internationally, such as the turn to post-structuralism, feminism and conceptualisations of multiculturalism and diversity. However, overall there have been no innovative and uniquely South African alternative theories and methodologies.

Instead, there has been a widespread acceptance of the deeply political nature of psychological knowledge. After the public acknowledgement of the complicity of psychology with apartheid at the 1994 national conference, which saw the demise of the previous predominantly white professional society, the Psychological Association of South Africa, and the launch of its more racially integrated successor, the Psychological Society of South Africa, ${ }^{3}$ South African psychology's claim to absolute neutrality was irreversibly demolished. This has been accompanied by changes in the curricula of Psychology Departments across South Africa. The emergence of community psychology as a distinctive field, as well as an increasing focus on issues of race, gender and ethnicity are arguably indications of the impact of the relevance debates of the late 1980s and early 1990s.

\section{TIME TO RE-EXAMINE RELEVANCE?}

But, perhaps the time is ripe for us to re-examine what we mean by relevance? Prior to 1994 relevance referred to an anti-apartheid critique and a shift in the subject of psychology as witnessed in the development of community psychology. Post 1994 relevance has surfaced in questions and projects which have sought to change the demographic profile of psychologists and in shifts towards more policy-driven research and projects.

Ten years into democracy perhaps it is time for us to re-think and extend our understanding of relevance to include not only a focus on issues of race and gender and responsiveness to policy, but also critical issues related to the nature of knowledge production in South Africa psychology. Should there be a greater focus on theory development? Are we doing enough basic research? Are our curricula covering 
issues at the cutting-edge of psychological knowledge? Do we have the appropriate methodological skills? These are some of the questions that may be relevant to the South Africa of the twenty-first century.

There have been wide-ranging developments in the socio-political environment since 1994. One of these has been the development of a national system of innovation and the adoption of a national research and development strategy. The point of departure for this strategy is the now universally accepted link between knowledge creation and economic and social development. The question of relevance within such a context is deeply complex. Many countries have grappled with the question of what relevance is and how one assesses it. The criteria for relevance and social impact are not easily identifiable. In considering such issues, van der Meulen and Rip (2000) pointed out that almost every research project can be legitimised by being linked to external issues, be they related to the environment, industry, culture or society. Referring to the case of the Netherlands, they showed that in order to mobilise resources in an increasingly competitive environment, over-optimistic claims of relevance tend to be made and that these claims are seldom realised. These authors further argued that the quest for relevance in contemporary research has led to a pattern of high expectations followed by disappointment, which typically is dealt with by adjusting expectations after the fact.

In many disciplines in the natural sciences bibliometric measures such as citation indices and impact factors are used as an indication of impact. However, for social science disciplines such as psychology these measures are not of much use, particularly to assess societal impact. Some important limitations of citation counts are the following: incorrect work may be highly cited, self-citation and gratuitous citation artificially inflate the counts, the size of different academic fields varies, methodological papers are among the most highly cited, and local journals that are nationally important may be excluded (Ho, 1998; Kostoff, 1995).

One of the reasons for the pattern of high expectations followed by disappointment is related to the time line between knowledge production and impact. The quest for social relevance is implicitly based on a very short time line between the research activity and take-up by society. We expect that any research project will lead to immediate social impact. Is this realistic and, moreover, is it appropriate?

As we move into ten years beyond democracy, it may be appropriate for us to pose new questions about the future of psychology. Questions such as: Is South African psychology innovative and dynamic? Is it appropriate to debate questions of relevance only in relation to national context or does a rapidly changing world demand that we begin to examine relevance in relation to our location in Africa and our positioning in the global socio-political context? It may be also time for us to raise questions about our disciplinary identity in a knowledge environment where boundaries between disciplines are becoming increasingly blurred and technological advances in the study of human genetics, brain research and neurology are producing new insights into questions that have traditionally been the unique focus of psychology. 


\section{NOTES}

1. Although the authors describe the trend as encouraging, a closer examination reveals that there was a less than $2 \%$ difference in the number of female versus male authors in the periods 1984 to $2001(43.6 \%)$ and 2002 to 2003 (45.4\%). It is questionable whether this represents any kind of trend at all, especially given the great variation observed over the entire decade.

2. It should be noted, however, that a number of articles regarding HIV/AIDS were published in the SAJP prior to the period included in Macleod's review (five such articles were published in the first issue of the 1995 edition alone). However, this does not detract from the point regarding the poor overall representation of articles dealing with what is one of South Africa's most urgent socio-political concerns.

3. At least with respect to the leadership positions in the organisation (Painter \& Terre Blanche, 2004).

\section{REFERENCES}

Berger, S. and S. Lazarus (1987). The views of community organisers on the relevance of psychological practice in South Africa. Psychology in Society, 7, 6-23.

Bodibe, R. C. (1993). What is the truth? Being more than just a jesting Pilate in South African psychology. South African Journal of Psychology, 23 (2), 53-58.

Dawes, A. (1985). Politics and mental health: The position of clinical psychology in South Africa. South African Journal of Psychology, 15, 55-61.

de la Rey, C and Owens, I. (1998). Perceptions of psycho-social healing and the Truth and Reconciliation Commission in South Africa. Peace and Conflict: Journal of Peace Psychology, 4(3), 257-270.

Duncan, N., Gqola, P., Hofmeyer, M., Shefer, T., Malunga F. and Mashige, M. (Eds), (2002). Discourses on difference, discourses on oppression. Cape Town: Centre for Advanced Studes of African Society (CASAS).

Foster, D., Pillay, Y. and Freeman, M. (1997) Mental health policy issues for South Africa. Cape Town: MASA

Hamber, B. (1998). The burdens of truth: An evaluation of the psychological support services and initiatives undertaken by the South African Truth and Reconciliation Commission. American Imago, 55, 9-28.

Hayes, G. (2003). PINS: 20 years of oppositional and critical psychology. Psychology in Society, 29, 1-5.

Ho, K.K. (1998). Research output among the three faculties of business, education, humanities and social sciences in six Hong Kong universities. Higher Education, 36, 195-208

Holdstock, T. (1981). Psychology in South Africa belongs to the colonial era: Arrogance or ignorance. South African Journal of Psychology, 11, 123-129.

Isemonger, I. (1990). A post-modern critique of community psychology. Psychology in Society, $13,37-41$.

Kaminer. D., Stein D., Mbanga I., Zungu-Dirwayi N. (2001). The Truth and Reconciliation Commission in South Africa: Relation to psychiatric status and forgiveness among survivors of human rights abuses. British Journal of Psychiatry, 178, 373-377.

Kostoff, R.N. (1995). Federal research impact assessment: Axioms, approaches, applications. Scientometrics, 34(2), 163-206. 
Louw, J. (1992). "To rule and own, or to live like shy deer": The dilemmas of a profession. Psychology in Society, 16, 49-60.

Macleod, C. (2004, July). Position paper: critical research issues in Psychology. The National Research Foundation's 'Shifting the boundaries of knowledge - the role of social sciences, law and humanities project'. <http://www.ru.ac.za/research/pdfs/macleod_thought_paper. pdf $>$. Accessed on 17 September 2004.

Magwaza, A. (2001). Submission to the South African Truth and Reconciliation Commission: The reflections of a commissioner on the culpability of psychology. In N. Duncan, A. van Niekerk, C. de la Rey and M. Seedat (Eds), Race, racism, knowledge production and psychology in South Africa. Huntington, New York: Nova Science, Publishers.

Naidoo, A. V. (1996). Challenging the hegemony of Eurocentric psychology. Journal of Community and Health Sciences, 2(2), 9-16

Nicholas, L. (2000). An evaluation of psychological reports considered in the amnesty process of the Truth and Reconciliation Commission. South African Journal of Psychology, 30, 50-52.

Painter, D. and Terre Blanche, M. (2004, February). Critical psychology in South Africa: Looking back and looking forwards. $<$ http://www.criticalmethods.org/collab/critpsy .htm>. Accessed on 17 September 2004

Seedat, M. (1998). A characterisation of South African psychology (1948-1988): The impact of exclusionary ideology. South African Journal of Psychology, 28(2), 74-85.

Seedat, M., Cloete, N. and Shochet, I. (1988). Community psychology: Panic or panacea, Psychology and Society, 11, 39-54.

Shefer, T. (1988). Mental health services in Nicaragua: Lessons for South Africa, Psychology in Society, 11, 31-38.

van der Meulen, B. and Rip, A. (2000). Evaluation of societal quality of public sector research in the Netherlands. Research Evaluation, 8 (1), 11-25.

van Niekerk, A., Diedricks, M., de la Rey, C., Shefer, T. and Duncan, N. (1998). Shifting the publications game: The case of a textbook project at a historically black university. Perspectives in Education, 17(2), 71-86. 
Copyright of South African Journal of Psychology is the property of South African Journal of Psychology and its content may not be copied or emailed to multiple sites or posted to a listserv without the copyright holder's express written permission. However, users may print, download, or email articles for individual use. 